\title{
Applying receptor models Unmix and PMF on real data set of elements in PM for sources evaluation of the sea coastal side region (Southeast Adriatic Sea)
}

\section{D. Đorđević ${ }^{1}$, S. Petrović ${ }^{2}$, D. Relić ${ }^{3}$, and A. Mihajlidi-Zelić ${ }^{3}$}

${ }^{1}$ ICTM - Centre of Chemistry, University of Belgrade, Studentski trg 12-16, 11000 Belgrade, Serbia

${ }^{2}$ ICTM - Centre of Catalysis, University of Belgrade, Studentski trg 12-16, 11000 Belgrade, Serbia

${ }^{3}$ Faculty of Chemistry, University of Belgrade, Studentski trg 12-16, 11000 Belgrade, Serbia

Received: 1 March 2013 - Accepted: 16 May 2013 - Published: 4 June 2013

Correspondence to: D. Đorđević (dragadj@chem.bg.ac.rs)

Published by Copernicus Publications on behalf of the European Geosciences Union.
Applying receptor models Unmix and PMF on real data set of elements in PM

D. Đorđević et al.

\section{Title Page}

\section{Full Screen / Esc}

Printer-friendly Version

Interactive Discussion 


\section{Abstract}

Two receptor modeling techniques were applied to a common data set of daily measurements of 11 elements in particulate matter (PM). Samples of PM were collected in the $5 \mathrm{yr}$ period at an urban site located at the sea coast. In the vicinity of the sam5 pling site traffic is a permanent but not significant anthropogenic source. In this study we used both the Unmix and PMF receptor models for evaluation of the sources contribution. Unmix found thirteen solutions for several combinations of species, but four solutions satisfy the criteria Min $R^{2}>0.8$ and Min $S / N>2$. Unmix identified three and four sources in satisfactory solutions. The PMF model has given 3 possible solutions and by further analysis the best solution of four sources was selected. $F$ peak refinement enabled finding a more realistic solution that includes re-suspension and traffic as dominant source contributions. The results given in this study are in accordance with the results of Enrichment Factors analysis presented in our previous work.

\section{Introduction}

15 Several multivariate receptor models like principal component analysis (PCA) and factor analysis (FA) have been useful in providing a relatively easy and accurate means for classifying sources (Lee et al., 2003). However, because PCA and FA analysis depend only on the covariance matrix, general requirements for the source contributions are not satisfied, e.g. negative values for factor loading and factor score often occur.

The Chemical Mass Balance (CMB) method is widely used to estimate contributions of emission sources to receptors. Weighted least-squares solutions are solved to an equation, which describes a mass balance between ambient concentration of each chemical species and a linear sum of products of source profiles and source contributions (Lee et al., 2009).

25 A state-of-the-art multivariate receptor models are applied in the diverse fields of environmentrics, chemometrics, geology and remote sensing. Multivariate receptor
AMTD

6, 4941-4969, 2013

Applying receptor models Unmix and PMF on real data set of elements in PM

D. Đorđević et al.

\section{Title Page}

\section{Full Screen / Esc}

Printer-friendly Version

Interactive Discussion 
modeling is a term applied in the field of air quality for the solution of the general linear mixture problem. For conservative chemical species, i.e. those that do not undergo reactions in the atmosphere, the principle of mass balance is applied. The mass balance for species $i$ can be written as:

${ }_{5} \quad C_{i j}=\sum_{k=1}^{N} a_{i k} S_{k j} i=1, \ldots, m, j=1, \ldots, n$.

In this equation, $C_{i j}$ is the observed concentration of species $i$ in sample $j, S_{k j}$ is the total amount of particulate mass from source $k$ in sample $j$ and $a_{i k}$ is the composition fraction of species $i$ from the source $k$. In air quality studies, the units of $C_{i j}$ are usually micrograms per cubic meter. Thus, since $a_{i k}$ is a dimensionless mass fraction, the 10 units of $S_{k}$ are also micrograms per cubic meter. Equation (1) is the physical basis of all receptor models. $C_{i j}$ is subject to random error and $a_{i k}$ to random variations (Henry, 2002).

Unmix seeks to solve the general mixture problem where the data is assumed to be a linear combination of an unknown number of sources of unknown composition, which contribute an unknown amount to each sample (Norris et al., 2007). Unmix assumes that the data and the compositions of the sources are all strictly positive (because of the effects of errors, small values less than zero are allowed in order to reduce the bias in the results). Unmix further assumes that for each source there are some samples that contain little or no contribution from that source. For a given selection of species, Unmix estimates the number of sources, the source composition, and source contributions to each sample. The usual analytical approach to fitting the model in Eq. (1) is to find the values of $a_{i k}$ and $S_{k j}$ that minimize the weighted mean square error $F$ (Henry, 2002) of the model:

$F=\sum_{i=1}^{m} \sum_{j=1}^{n}\left(w_{i j} C_{i j}-\sum_{k=1}^{N} a_{i k} S_{k j}\right)^{2} i=1, \ldots, m, j=1, \ldots, n$.
AMTD

$6,4941-4969,2013$

Applying receptor models Unmix and PMF on real data set of elements in PM

D. Đorđević et al.

Title Page

Abstract Introduction

Conclusions

References

Tables Figures

14

4

Back

Close

Printer-friendly Version

Interactive Discussion 
The General Mixture Problem and the special case of multivariate receptor modeling are ill posed problems. There are simply more unknowns than equations and thus there are many wildly different solutions that are all equally good in the least-squares sense. In a statistical way these problems are not identifiable. One approach to ill-posed prob5 lems is to impose conditions that add additional equations, which then define more realistic solutions to be closer to unique solution. The non-negativity conditions as additional conditions are imposed by the physical nature of the problem (Henry, 2001). Source composition and contributions must be non-negative but non-negativity conditions alone are not sufficient to give a unique solution. More constraints are needed 10 (Henry, 1987). Under certain, rather mild conditions, the data themselves can provide the needed constrains (Henry, 1997). This is how Unmix works.

Based on the multivariate factor analysis and the results in factor profiles and contributions, Paatero and Tapper (Paatero and Tapper, 1993; Paatero and Tapper, 1994; Paatero, 1997) established the advanced factor analysis method - positive matrix factorization (PMF). Several features are incorporated in this model:

- weights data points by their analytical uncertainties,

- constrains factor loadings and factor scores to non-negative values and thereby minimizes the ambiguity caused by rotating the factors,

- uses weighted least-squares fits for data,

- expresses factor loadings in mass units, which allows factors to be used directly as source signatures,

- provides uncertainties for factor loadings and factor scores.

In PMF, the matrix $\mathbf{X}(n \times m)$ includes measured mass concentrations, and is represented as the sum of the product of $\mathbf{G}(n \times p)$ and $\mathbf{F}(p \times m)$ matrices and the resid- ual matrix $\mathbf{E}(n \times m)$, where $n$ is the number of samples, $m$ is the number of chemical
AMTD

6, 4941-4969, 2013

Applying receptor models Unmix and PMF on real data set of elements in PM

D. Đorđević et al.

Title Page

Abstract Introduction

Conclusions

Tables References Figures

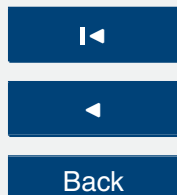

$>1$

Back

Close

Full Screen / Esc

Printer-friendly Version

Interactive Discussion 
species, and $p$ is the number of independent source types. This model can give a solution that can be displayed in matrix form:

$\mathbf{X}=\mathbf{G} \cdot \mathbf{F}+\mathbf{E}$.

The object function $Q$ that is to be minimized is defined as:

${ }_{5} Q=\sum_{i=1}^{n} \sum_{j=1}^{m}\left(\varepsilon_{i j} / u_{i j}\right)^{2}$

where $u_{i j}$ is the uncertainty of the species $j$ in a sample $i$ and residuals $\varepsilon_{i j}$ i.e. the portion of the measured concentration that cannot be explained by the model is defined by:

$\varepsilon_{i j}=x_{i j}-\sum_{k=1}^{p} g_{i k} f_{k j}$.

$10 g_{i k}$ is the concentration contribution of source $k$ to sample $i$ and $f_{k j}$ (source profiles) is the fractional concentration of species $j$ in the emissions from source $k$.

In addition, non-negativity constraints should be fulfilled, meaning that all the elements in Gand $\mathbf{F}$ are to be non-negative. The main process of the PMF is minimizing the $Q$ value which is defined in the Eq. (4) as the sum of square of the residuals $\left(\varepsilon_{i j}\right)$ 15 weighted inversely with uncertainty $\left(u_{i j}\right)$ of the data point (Polissar et al., 1998; Lee and Hopke, 2006). The procedure of Polissar et al. (1998) was used in this study to calculate uncertainties in the species concentrations. Briefly, for the data below detection limit (DL), the concentrations were replaced with the value $\mathrm{DL} / 2$ and the uncertainty was set as:

\section{Applying receptor models Unmix and PMF on real data set of elements in PM}

D. Đorđević et al.

Title Page

Abstract Introduction

Conclusions

References

Tables

Figures

14

4

Back

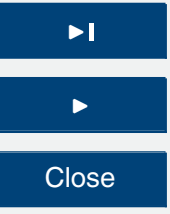

Full Screen / Esc

Printer-friendly Version

Interactive Discussion 
For the missing data, concentrations were replaced by the geometric mean and the respective uncertainty was set at four times of this mean concentration. PMF provides uncertainties in factor profiles $\left(\sigma_{f k j}\right)$, defined as the standard deviation of 100 bootstrapping runs.

$5 \quad$ The solution of Eq. (4) is obtained by iteration until convergence is reached.

The output from the PMF model is a set of factors representing source profiles and estimates of their associated contributions to measured concentrations at the sampled receptor sites. Interpretation of the factors (i.e. allocation to names source types) has to be done by reference to information on source emissions, derived from literature 10 and/or available measured data.

Numerous studies employing both the PMF and Unmix models have been done in recent years (Pekney et al., 2006; Poirot et al., 2001; Kim et al., 2004; Chen et al., 2007 in: Hegg et al., 2010). The models tend to be more or less in agreement with large data sets, but differences of a factor of two in the contribution of identified similar sources 15 to particular samples are not uncommon (Hegg et al., 2010). Typically, Unmix resolves fewer factors than PMF and very importantly for our purposes - the nature of the factors resolved is much more dependent on the precise choice of input species than is the case for PMF (Maykut et al., 2003) Unmix will, in many instances, not yield a feasible solution if certain species are (or are not) included in the input and one commonly ends

\section{set (Hegg et al., 2010).}

Paatero's positive matrix factorization (PMF) approach weights the data by the inverse of the measurement error for each observation. A major advantage of this approach is that the missing data can be included as observations with a large error. 25 However, the minimization of $\mathbf{F}$ is still an ill-posed problem, or in other words, the model is not identifiable. Even the inclusion of the non-negative constraints does not provide an identifiable model. Paatero addresses this problem, which he named rotationally indeterminacy, by adding one or more user-selected parameters. Park et al. (2002) have used modern constrained minimization methods on $F$ along with specific conditions,

\section{AMTD}

$6,4941-4969,2013$

Applying receptor models Unmix and PMF on real data set of elements in PM

D. Đorđević et al.

Title Page

Abstract Introduction

Conclusions

Tables References Figures

14

4

Back

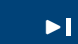

D

Close

\section{Full Screen / Esc}

Printer-friendly Version

Interactive Discussion 
e.g. each source composition must have at least one species absent from that source. Finally, Paatero has generalized $F$ in a natural way to include the estimation of even more unknown parameters associated with spatial variations (Henry, 2002). Source apportionment by factors with explicit restrictions (SAFER) and Unmix finish the list

5 of the selfmodeling curve resolution-based models. SAFER uses additional physical constrains on the source composition that must be supplied by the user. Linear programming is then applied to find the small regions that must contain the source points. Unmix uses the data to define edges, which are used to find the source points. Unmix can use additional physical constraints supplied by the user. At this time, this is 10 limited to the identification of a species as a tracer, i.e. a species with effectively only one source. Currently, SAFER and Unmix (Henry, 2002, 2003) and Multilinear Engine ME-2 as a part of PMF 3.0 (Valentin et al., 2008)) are the frequently used methods that allow the additional physical constraints that can make use of the users' knowledge of the problem.

15 The main goal of this study is applying Unmix and PMF models on a data base that was previously submitted to other models; Principal Component Analysis (PCA) and Enrichment Factors (EA) have already indicated the main effects. Since Unmix and PMF are still under development, this analysis is useful for comparing results and evaluating models.

Multivariate source apportionment models, Unmix and positive matrix factorization (PMF), often produce nearly the same source apportionment, however some investigations have shown that this is not always the case (Henry and Christensen, 2010). These models do not specify a minimum number of samples, but the stability of their solutions increases with the number of samples (Chen et al., 2007). In this study, we calculated sources composition and sources contributions of elements in PM using real data base. The real data set of 11 trace elements in particulate matter (PM) obtained in
AMTD

$6,4941-4969,2013$

Applying receptor models Unmix and PMF on real data set of elements in PM

D. Đorđević et al.

Title Page

Abstract Introduction

Conclusions

References

Tables Figures

14

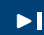

4

Back

Close

Full Screen / Esc

Printer-friendly Version

Interactive Discussion 
252 observations was analyzed by Unmix 6.0 and PMF 3.0. The sampling site is situated only $10 \mathrm{~m}$ away from the coast of the Adriatic Sea. Samples of PM were subjected to gravimetric analysis for determination of total mass concentrations and subsequently to elemental analysis for $\mathrm{Fe}, \mathrm{Mn}, \mathrm{Ti}, \mathrm{Pb}, \mathrm{Cr}, \mathrm{Cu}, \mathrm{Cd}, \mathrm{Co}, \mathrm{Ni}, \mathrm{Hg}$ and $\mathrm{Se}$. Suspended 5 particles were collected using a high-volume Aerosol Sampler, AQUERO model 400XT sampling system, on boron-silicate fibreglass filters every sixth day as a $24 \mathrm{~h}$ sample. The sampler was located in the town of Herceg-Novi (Fig. 8) $18^{\circ} 33^{\prime \prime} \mathrm{N}, 42^{\circ} 27^{\prime \prime}$. The meteorological station is part of the MED POL program. The nearest road is located about $100 \mathrm{~m}$ north of the meteorological station. There are no significant grassy areas around the meteorological station, and there is no considerable construction work in progress. The terrain surrounding the receptor is rocky with some small areas of soil (Đorđević et al., 2004). Filters were digested with $\mathrm{HNO}_{3}$. A Flame Atomic Absorption Spectrometry (F-AAS), Varian AAS-Spectr AA 55 instrument, was used to measure the concentrations of $\mathrm{Cd}, \mathrm{Co}, \mathrm{Cr}, \mathrm{Cu}, \mathrm{Ni}, \mathrm{Pb}, \mathrm{Ti}, \mathrm{Fe}$ and $\mathrm{Mn}$. The concentrations of $15 \mathrm{Hg}$ and Se were determined by the hydride vapor AAS method (HV-AAS) (Đorđević et al., 2005). The maximum expanded uncertainty of measurements for all elements was about $5 \%$.

\section{Results of the Unmix model}

The applied Unmix and PMF models were available on the EPA Internet site (www.epa. 20 gov). Unmix and PMF used in this study do not limit the number of factors.

The following initial operations were subjected to the Unmix model data: Suggest Exclusion, Initial Species, Additional Species including SAFER and Initial Points. PM was chosen for the total and for the normalization.

The data was screened using the signal-to-noise ratio (Min $S / N$ ratio) criteria higher 25

\section{AMTD}

$6,4941-4969,2013$

Applying receptor models Unmix and PMF on real data set of elements in PM

D. Đorđević et al.

\section{Title Page} used for sources estimation. The agreement between the true and estimated source contribution (Min $R^{2}$ ) was considered as well (Henry, 2003, EPA/600/R-07/089). 
Figure 1 shows the comparison of measured and the predicted concentrations of $\mathrm{PM}$ and trace elements in PM through time series and Min $R^{2}$. Model Unmix did not calculate $R^{2}$ values for $\mathrm{Cd}$, Co, $\mathrm{Hg}$ and $\mathrm{Se}$ and neither satisfactory solution included these elements. Min $R^{2}$ values are given in Table 1 .

5 From statistical parameters displayed for each species, after input data and the following operations: Suggest exclusion, Influential points, Initial species, Additional species and SAFER, Unmix finds six combinations of species that give any kind of solution (Table 2). Min $S / N$ for each principal component greater than 2 and Min $R^{2}$ greater than 0.8 of all combinations of elements estimated by Unmix were selected as 10 good solutions that are in accordance with the Unmix criteria (Henry, 2003). Thirteen solutions in total were found, but four solutions satisfy the above criteria, signed in bold in Table 2. Parameters given for these solutions are also Significant/Strong Species in Sources (sigma-based).

Taking into account the calculated good solutions presented in Table 2, the Edges 15 plots were done for these solutions (Fig. 2). In the first solution (combination of species $\mathrm{Mn}-\mathrm{Ti}-\mathrm{Pb}-\mathrm{Cr}-\mathrm{Cu}$, 3 Sources Solution) the second and third source are well defined by many points on the $y$-axis while source 1 has just a few points on the $x$-axis.

The second solution (combination of species Fe-Mn-Ti-Pb, 3 Sources Solution) does not show good accumulation of points on the $x$ and $y$-axes.

The third solution (combination of species Fe-Mn-Ti-Pb-Cr-Cu-Ni, 4 Sources Solution) shows the edges on the $y$-axis defined by many points for the third and the fourth source, but the $x$-axis has just a few points.

In the fourth solution (combination of species Fe-Mn-Ti-Pb-Cr-Cu, 3 Sources Solution) good accumulation of points are on the $y$-axis, for sources 2 and 3 while the $x$-axis 25 has just a few points for source 1 (Fig. 2).

The source profile of the solutions chosen according to the criteria $S / N>2$ and $R^{2}>2$ are given in Fig. 3 .

\section{AMTD}

6, 4941-4969, 2013

Applying receptor models Unmix and PMF on real data set of elements in PM

D. Đorđević et al.

Title Page

Abstract Introduction

Conclusions

Tables

References

Figures

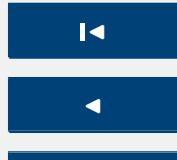

$>1$

Back

Close

\section{Full Screen / Esc}

Printer-friendly Version

Interactive Discussion 


\section{Results of the PMF model}

At the first set up all elements are labeled as Strong, since (the signal/noise ratio) $S / N>2$ for all of them. Based on input data statistics, residuals show bimodal distribution in the case of $\mathrm{Ni}, \mathrm{Mn}$, and $\mathrm{Hg}$, so their uncertainties are increased labeling them 5 as Weak. Selenium is excluded from the model because of a very small contribution and the correlation factor, while for cadmium more than $50 \%$ of samples are below the detection limit.

The $Q$ value represents the goodness-of-fit and assesses how the model fits the experimental data. $Q_{\text {true }}$ is calculated taking into account all data points while $Q_{\text {robust }}$ 10 is calculated accounting for outlier points. Data with scaled residuals above 4 are regarded as outlier points.

The $F$ peak function is used to rotate the data set, make fine tuning and improvement of the model in the case of data with high noise (positive values $F$ peak) or clean data (negative values $F$ peak). Normally, the default settings give satisfactory results, but in 15 some cases subsequent adjustments are needed.

Bootstrapping is an advanced analysis that examines the stability of solutions of the tested models. The bootstrap method is essentially based on resampling methods in which "new" data sets that are consistent with the original data are generated. Each "new" data set (which is essentially a subset of the original database), is decomposed into profile and contribution matrices, and the resulting profile and contribution matrices are compared with the base run (Eberly, 2005), giving the distribution for each species to evaluate the stability of the solution.

To ensure the robustness of statistics, 300 bootstrap runs were performed, while the default value of the minimum correlation ( $R$ value) of 0.60 was used.

25 The application of positive matrix factorization to solve the number and profile of the sources applied to a database of measured concentrations of elements (Đorđević et al., 2005) resulted in obtaining possible solutions for 3,4 and 5 sources. For 6 or more sources the model does not find the convergence of the functions $Q$, which implies that
AMTD

$6,4941-4969,2013$

Applying receptor models Unmix and PMF on real data set of elements in PM

D. Đorđević et al.

\section{Title Page}


the model did not find any minima. Varying simulation conditions did not contribute to significant improvement, even when the uncertainty is significantly increased. Therefore possible solution should be sought among three possible cases. The lack of a solution with a larger number of sources was reflected in the inability to use the IM 5 the maximum individual column mean and IS - the maximum individual column standard deviation (Lee et al., 1999), which would be helpful to find the true number of sources.

Table 3 shows the categories of elements and the $R^{2}$ values for each of the three possible solutions.

10 Each of the possible solutions obtained by PMF analysis will be considered. Figure 4 shows $F$ peak strengths for 3 sources solution (Fig. 4a), 4 sources solution (Fig. 4b) and 5 sources solution (Fig. 4c).

3 Sources Solution: the relatively good correlation was obtained only for $\mathrm{Cr}$ and $\mathrm{Pb}$, while bimodal distribution is still present in the case of $\mathrm{Co}, \mathrm{Ti}$ and $\mathrm{Fe}$. Also, significant outliers are present in the model. In addition, G-Space plots show considerable interaction between the sources 1 and 3 .

Rotational ambiguity, which was found between the sources 1 and 3 , decreases when the value of Strength factor reaches -1.2 (Fig. 4a). This is mostly reflected in the increase of Ti concentration in the source 2.

However, a small degree of correlation between the model and database indicates that the model with three sources is insufficient to adequately describe a number of sources.

In this case, only $\mathrm{Co}, \mathrm{Ni}$ and $\mathrm{Fe}$ show relatively good interquartile range of about $20 \%$, while other species show considerable variation and therefore represent a less stable solution. This is especially pronounced in the case of $\mathrm{Hg}, \mathrm{Cr}$ and $\mathrm{Mn}$. Also, in some cases $(\mathrm{Hg}, \mathrm{Ti})$ base run values are not within the interquartile range in the bootstrapping of results. This is probably a consequence of assuming the model with only three sources. Profiles of sources are given in Fig. 5 .

\section{AMTD}

$6,4941-4969,2013$

Applying receptor models Unmix and PMF on real data set of elements in PM

D. Đorđević et al.

Title Page

Abstract Introduction

Conclusions

Tables

References

Figures

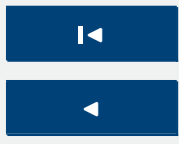

$>$ I

Back

Close

\section{Full Screen / Esc}

Printer-friendly Version

Interactive Discussion 
4 Sources Solution: the model with four sources shows a significantly better correlation with measured concentrations of elements. Although the agreement of time series for $\mathrm{Ti}$ and $\mathrm{Cr}$ is excellent $\left(R^{2}>0.95\right)$, and for Pb satisfactory $\left(R^{2}=0.70\right)$, in the case of other elements there are still episodes with very high concentrations that this 5 model cannot fit. It should be noted that $\mathrm{Cu}$ shows very good agreement between the predicted and observed concentrations, but the existence of outliers have reduced the correlation to 0.34. A small degree of correlation in the case of Co is the result of a significant number of measurements below the detection limit.

Bimodal distribution is still present in the case of $\mathrm{Ni}$ and $\mathrm{Hg}$. G-Space plot shows 10 some interaction between sources 1-3, 2-3, 3-4.

For a model with four sources, rotational ambiguity disappears when the $F$ peak strength reaches -0.8 (Fig. $4 \mathrm{~b}$ ). This rotation is mostly reflected in the increase of $\mathrm{Ti}$ content in source 1, and largely in sources 2 and 3 . On the other hand, this may just mean that the content of titanium in this solution is divided among several sources. It 15 is necessary to consider these results carefully and determine whether there is justification for it to be included in further consideration of the composition of the sources.

The existence of significant unmapped results indicates that only the relative stability of the obtained solutions is achieved. Interquartile ranges in the case of $\mathrm{Fe}, \mathrm{Pb}, \mathrm{Cu}$ and $\mathrm{Cr}$ are about $20 \%$, while in the case of other species this range is much higher indicating the instability of the solution. Base run values which are not within the interquartile range in the bootstrapping of the results are, in the case of $\mathrm{Cu}, \mathrm{Mn}, \mathrm{Pb}$ and especially $\mathrm{Hg}$, calculated by the model only in the fourth source.

5 Sources Solution: The model and data from the database show agreement $\left(R^{2}\right)$ over $90 \%$ for $\mathrm{Cr}, \mathrm{Ti}, \mathrm{Fe}$ and $\mathrm{Pb}$, while just over $50 \%$ for $\mathrm{Mn}$. The model also fits $\mathrm{Cu}$ real data very well, and the correlation of 0.47 is caused by significant outliers that are related to individual episodes of $\mathrm{Cu}$ emissions. In spite of the increased uncertainty $\mathrm{Mn}, \mathrm{Ni}, \mathrm{Co}$ and $\mathrm{Hg}$ show a lack of fit.

G-Space plot only shows some rotational ambiguity in the case of sources: $2-5,3-5$ and 4-5.

\section{AMTD}

$6,4941-4969,2013$

Applying receptor models Unmix and PMF on real data set of elements in PM

D. Đorđević et al.

\section{Title Page}

Abstract Introduction

Conclusions

Tables References Figures

14

4

Back

Full Screen / Esc

Printer-friendly Version

Interactive Discussion 
The $F$ peak in the range -2 to 2 (Fig. 4c) showed the most impact on the sources of $\mathrm{Cu}$, especially at higher strength values, while the ambiguity between the sources mentioned above still exists. The peak $F$ curve is generally symmetrical in the examined interval.

5 In the case of five sources there are also unmapped results, suggesting a reduced stability of the solution. In general, the most stable solutions are obtained for those elements that are present in the source with the highest percentage (interquartile range then is approximately $15 \%$ ). This is the case for $\mathrm{Fe}, \mathrm{Pb}, \mathrm{Ti}$. A slightly worse result of the bootstrap analysis is obtained for $\mathrm{Cu}, \mathrm{Mn}, \mathrm{Cr}$, $\mathrm{Co}$ and $\mathrm{Ni}$ (interquartile ranges are equal 10 or higher than $20 \%$ ). The least stable solution is for $\mathrm{Hg}$ with considerable dispersion in the bootstrap analysis solutions. However, it should be noted that the interquartile and $R^{2}$ value from Table 3 for the corresponding elements are in agreement.

\section{Discussion}

In our previous work (Đorđević et al., 2005) we applied the PCA method on this data 15 set and 4 significant groups of sources contributions were found. The dominant factor (F1) is represented by the contribution sources of $\mathrm{Fe}, \mathrm{Mn}, \mathrm{Ti}, \mathrm{Cu}$ and $\mathrm{Pb}$. The following contribution sources were identified: re-suspension combined with the transport of Saharan dust from North Africa (Fe, Mn, Ti), re-suspended Saharan dust that had previously settled ( $\mathrm{Fe}, \mathrm{Mn}, \mathrm{Ti})$ and settled combustion products, originating from traffic, and probably some local stationary source $(\mathrm{Cu}, \mathrm{Pb})$. The remaining three factors represent the following combinations $\mathrm{F} 2$ by $\mathrm{Cr}$ and $\mathrm{Ni}, \mathrm{F} 3$ by $\mathrm{Cd}$ and $\mathrm{Se}$ and F4 by $\mathrm{Hg}$ and $\mathrm{Co}$. Also, the Enrichment Factors model revealed that in the region of the investigated receptor, the main contribution source of $\mathrm{Fe}, \mathrm{Mn}$ and $\mathrm{Ti}$ is the process of local re-suspension and that local re-suspension has no influence on the content of $\mathrm{Se}$ in the atmospheric aerosol. The re-suspension is the dominant emission source of $\mathrm{Cd}$ from the south-southeast direction from the nearby peninsula (Luštica) but this source is not permanent. The re-suspension also contributes to the contents of $\mathrm{Pb}, \mathrm{Ni}, \mathrm{Cr}, \mathrm{Cu}$

\section{AMTD}

$6,4941-4969,2013$

Applying receptor models Unmix and PMF on real data set of elements in PM

D. Đorđević et al.

Title Page

Abstract Introduction

Conclusions

Tables

References Figures

14

4

Back

Close

Printer-friendly Version

Interactive Discussion 
and $\mathrm{Co}$ as a consequence of their deposition in the vicinity of the receptor after being emitted from anthropogenic sources in the region (Đorđević et al., 2005).

The Unmix model excluded the following elements from the calculation: $\mathrm{Cd}, \mathrm{Co}, \mathrm{Hg}$ and $\mathrm{Se}$. In the first satisfactory solution for Mn-Ti-Pb-Cr-Cu combination Unmix found

53 sources (Table 2, Fig. 3a). Pb is strong in the first source and this source can be attributed to traffic. In the second source $\mathrm{Cr}$ and $\mathrm{Cu}$ are strong and $\mathrm{Ti}$ and $\mathrm{Mn}$ are significant. This source can be re-suspension of elements previously settled from anthropogenic sources. In the third source neither element is strong or significant.

In the second satisfactory solution for Fe-Mn-Ti-Pb combination of elements it also 10 found 3 sources (Table 2, Fig. 3b). This solution has the best values of Min $R^{2}$ and Min $S / N$ compared to all combinations. The first and the third source contain $\mathrm{Pb}$ which is a tracer for traffic. In the third source $\mathrm{Pb}$ is strong, and it is reasonable to associate this source with traffic, while the first source could be local re-suspension. The second source in this combination could be a long range transport of Saharan dust since it 15 contains crustal elements.

In the third and the fourth solution, the sources where $\mathrm{Pb}$ is strong can be attributed to traffic; namely, source 3 for Fe-Mn-Ti-Pb-Cr-Cu-Ni combination (Table 2, Fig. 3c) and source 1 for Fe-Mn-Ti-Pb-Cr-Cu combination (Table 2, Fig. 3d). Another source in which $\mathrm{Pb}$ is present as significant but not strong could be re-suspension. Source 4 for $20 \mathrm{Fe}-\mathrm{Mn}-\mathrm{Ti}-\mathrm{Pb}-\mathrm{Cr}-\mathrm{Cu}-\mathrm{Ni}$ combination and source 2 for Fe-Mn-Ti-Pb-Cr-Cu combination could be attributed to re-suspennsion, probably from various locations depending on wind directions. The contribution sources of $\mathrm{Fe}, \mathrm{Mn}, \mathrm{Ti}, \mathrm{Cu}$ and $\mathrm{Pb}$ are re-suspension of previously settled Saharan dust (Fe, $\mathrm{Mn}$ and $\mathrm{Ti}$ ) and combustion products from traffic, combined with a long-range transport of Saharan dust from North Africa. Factors 25 containing $\mathrm{Cr}$ and $\mathrm{Ni}$ indicate the existence of an anthropogenic emission source in the region. More precisely, in the northern segment at a distance of $100 \mathrm{~km}$ from the receptor, there is a slag heap, as well as a Coal Fired Power Plant - in Pljevlja and the Ironworks Nikšić (Đorđević et al., 2005).

\section{AMTD}

$6,4941-4969,2013$

Applying receptor models Unmix and PMF on real data set of elements in PM

D. Đorđević et al.

Title Page

Abstract Introduction

Conclusions

Tables References Figures
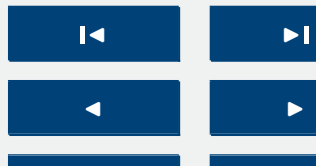

Back

Close

\section{Full Screen / Esc}

Printer-friendly Version

Interactive Discussion 
When discussing the number and origin of pollution sources, it is preferred to take into account the real situation on the field. In this case the following sources that contribute to the overall PM deposition can clearly be predicted: marine aerosols, traffic, re-suspension from the ground, probably some local stationary source, as a shipyard 5 located in the vicinity. Based on these obvious sources, PMF analysis solution with only three sources is exempt from further consideration.

In the case of PMF solution of five sources it may be noted that source No. 5 (Fig. 7), in which $\mathrm{Co}, \mathrm{Cu}, \mathrm{Ni}$ and $\mathrm{Mn}$ are present, can be described rather as a splitting factor than as a separate source. The most realistic solution that is imposed upon a detailed 10 analysis is the solution with four sources (Fig. 6).

Identification of sources was carried out and it agrees with the results of the Enrichment Factors analysis well (Đorđević et al., 2005). The $F$ peak profiles shown in Fig. 6 in rotation of data set for -0.8 , increase the contents of $\mathrm{Ti}$, in the case of sources 2 and 4.

15 Source 1 has been identified as re-suspension in combination with the long-range transport of Saharan dust. Figure 8 shows that the prevailing wind directions are over open sea.

Source 2 is attributed to the re-suspension coming from the direction of the nearby peninsula (Luštica), indicated in our previous work. Titanium found by $F$ peak is in better accordance with the Enrichment Factors analysis (Đorđević et al., 2005).

Source 3 corresponds to the composition of the particles that come from some anthropogenic source.

Source 4 with the highest content of $\mathrm{Pb}$, is characteristic for urban traffic. $F$ peak is increasing the value for Ti which is in better agreement with the traffic profile.

\section{Conclusions}

In this study we have used concentrations of elements in PM measured in the urban area of a coastal city in the south east of the Adriatic Sea. The real data set of eleven 4955

\section{AMTD}

$6,4941-4969,2013$

Applying receptor models Unmix and PMF on real data set of elements in PM

D. Đorđević et al.

Title Page

Abstract Introduction

Conclusions

References

Tables Figures

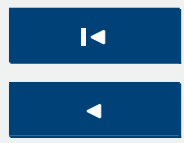

$>$ I

Back

Close

Printer-friendly Version

Interactive Discussion 
trace elements in PM obtained in 252 observations was analyzed by Unmix 6.0 and PMF 3.0. By applying Unmix to the real data set we found four satisfactory solutions in terms of modeling. The PMF model has given 3 possible solutions and by further analysis the best solution of four sources was selected. $F$ peak refinement was en5 abled to find a more realistic solution. This solution indicated re-suspension and traffic as dominant source of contribution. All of these solutions are in accordance with the Enrichment Factors shown in our previous work.

Acknowledgements. The authors gratefully acknowledge the financial support of the Ministry of Education and Science of the Republic of Serbia, which supported this research within the

\section{References}

Chen, L.-W. A., Watson, J. G., Chow J. C., and Magliano, K. L.: Quantifying $\mathrm{PM}_{2.5}$ Source Contributions for the San Joaquin Valley with Multivariate Receptor Models, Environ. Sci. Technol., 41, 2818-2826, 2007.

15 Đorđević, D., Vukmirović, Z., Tosić, I., and Unkasević, M.: Contribution of dust transport and resuspension to particulate matter levels in the Mediterranean atmosphere, Atmos. Environ., 38, 3637-3645, 2004.

Đorđević, D., Mihajlidi-Zelić, A., and Relić, D.: Differentiation of the contribution of local resuspension from that of regional and remote sources on trace elements content in the atmospheric aerosol in the Mediterranean area, Atmos. Environ., 39, 6271-6281, 2005.

Eberly, S.: EPA PMF 1.1 user's guide, http://www.epa.gov/heasd/products/pmf/users_guideold. pdf, Prepared by the US Environmental Protection Agency, National Exposure Research Laboratory, Research Triangle Park, NC, 2005.

Hegg, D. A., Covert, D. S., Jonsson, H. H., and Woods, R. K.: The contribution of anthropogenic 25 aerosols to aerosol light-scattering and CCN activity in the California coastal zone, Atmos. Chem. Phys., 10, 7341-7351, doi:10.5194/acp-10-7341-2010, 2010.

Henry, R. C.: Current Factor Analysis Receptor Models are III-Posed, Atmos. Environ., 21, 1815-1820, 1987.

AMTD

$6,4941-4969,2013$

Applying receptor models Unmix and PMF on real data set of elements in PM

D. Đorđević et al.

Title Page

Abstract Introduction

Conclusions

References

Tables Figures

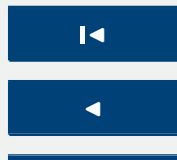

$>1$

Back

Close

Printer-friendly Version

Interactive Discussion 
Henry, R. C.: History and Fundamentals of Multivariate Air Quality Receptor Models, Chemometr. Intell. Lab., 37, 525-530, 1997.

Henry, R. C.: UNMIX Version 2.4 Manual, US Environmental Protection Agency, Research Triangle Park, NC, 2001.

5 Henry, R. C.: Multivariate receptor models-current practice and future trends, Chemometr. Intell. Lab., 60, 43-48, 2002.

Henry, R. C.: Multivariate receptor modeling by $\mathrm{N}$-dimensional edge detection, Chemometr. Intell. Lab., 65, 179-189, 2003.

Henry, R. C. and Christensen, E. R.: Selecting an Appropriate Multivariate Source Apportionment Model Result, Environ. Sci. Technol., 44, 2474-2481, 2010.

Kim, E., Hopke, P. K., Larson, T. V., and Covert, D. S.: Analysis of ambient particle size distributions using Unmix and positive matrix factorization, Environ. Sci. Technol., 38, 202-209, 2004.

Lee, E., Chan, C. K., and Paatero, P.: Application of positive matrix factorization in source ap15 portionment of particulate pollutants in Hong Kong, Atmos. Environ., 33, 3201-3212, 1999.

Lee, J. H. and Hopke, P. K.: Apportioning sources of $\mathrm{PM}_{2.5}$ in St. Luis, MO using speciation trends network data, Atmos. Environ., 40, S360-S377, 2006.

Lee, J. H., Lim, J. M., Kim, K. H., Chung, Y. S., and Lee, K. Y.: Trace element levels of aerosols at an urban area of Korea by instrumental neutron activation analysis, J. Radioanal. Nucl. 20 Ch., 256, 553-560, 2003.

Lee, D., Balachandran, S., Pachon, J., Shankaran, R., Lee, S., Mulholland, J. A., and Russell, A. G.: Ensemble-Trained $\mathrm{PM}_{2.5}$ Source Apportionment Approach for Health Studies, Environ. Sci. Technol., 43, 7023-7031, 2009.

Maykut, N. N., Lewtas, J., Kim, E., and Larson, T. V.: Source apportionment of $\mathrm{PM}_{2.5}$ at an 25 urban IMPROVE site in Seattle, Washington, Environ. Sci. Technol., 37, 5135-5142, 2003.

Norris, G. A., Vedantham, R., and Duvall, R. M.: EPA UNMIX 6.0 User Guuide, EPA/600/R07/089 (NTIS PB2007-112630), US Environmental Protection Agency, Washington, DC, 2007.

Paatero, P.: Least squares formulation of robust non-negative factor analysis, Chemometr. Intell. $30 \quad$ Lab., 37, 23-35, 1997.

Paatero, P. and Tapper, U.: Analysis of different modes of factor analysis as least square fit problem, Chemometr. Intell. Lab., 18, 183-194, 1993.

AMTD

6, 4941-4969, 2013

Applying receptor models Unmix and PMF on real data set of elements in PM

D. Đorđević et al.

Title Page

Abstract Introduction

Conclusions

References

Tables Figures

14

4

Back

Close

Full Screen / Esc

Printer-friendly Version

Interactive Discussion 
Paatero, P. and Tapper, U.: Positive Matrix Factorization: a non-negative factor model with optimal utilization of error estimates of data values, Environmetrics, 5, 111-126, 1994.

Park, E. S., Spiegelman, C. H., and Henry, R. C.: Bilinear estimation of pollution source profiles and amounts by using multivariate receptor models, Environmetics, 13, 775-798, 2002.

5 Pekney, N. J., Davidson, C. I., Robinson, A., Zhou, L., Hopke, P., Eatough, D., and Rogge, W. F.: Major source categories for $\mathrm{PM}_{2.5}$ in Pittsburgh using PMF and UNMIX, Aerosol Sci. Tech., 40, 910-924, 2006.

Poirot, R. L., Wishinski, P. R., Hopke, P. K., and Polissar, A. V.: Comparative application of multiple receptor methods to identify aerosol sources in Northern Vermont, Environ. Sci.

10 Technol., 35, 4622-4636, 2001.

Polissar, A. V., Hopke, P. K., Paatero, P., Malm, W. C., and Sisler, J. F.: Atmospheric aerosol over Alaska 2. Elemental composition and sources, J. Geophys. Res., 103, 19045-19057, 1998.

US Environmental Protection Agency, EPA Unmix 6.0 Model, http://www.epa.gov/heasd/ products/Unmix/Unmix.htm, last access: June 2007.

US Environmental Protection Agency, EPA Positive Matrix Factorisation 3.0, http://www.epa. gov/heasd/products/pmf/pmf_registration.htm.htm, last access: July 2008.

Valentin, A. L., Rami Alfarra, M., Urs, B., Brigitte, B., Christoph, H., Sönke, S., Miriam, N. W., Lukas, W., Silke, W., Alexandre, C., Puxbaum, H., and Andre, S. H. P.: Source Attribution of Submicron Organic Aerosols during Wintertime Inversions by Advanced Factor Analysis of Aerosol Mass Spectra, Environ. Sci. Technol., 42, 214-220, 2008.

AMTD

6, 4941-4969, 2013

\section{Applying receptor} models Unmix and PMF on real data set of elements in PM

D. Đorđević et al.

Title Page

Abstract Introduction

Conclusions

References

Tables Figures
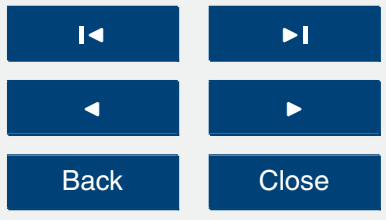

Back

Full Screen / Esc

Printer-friendly Version

Interactive Discussion 


\section{AMTD}

6, 4941-4969, 2013

\section{Applying receptor models Unmix and PMF on real data set of elements in PM \\ D. Đorđević et al.}

Table 1. $R^{2}$ values obtained by Unmix of measured and the predicted concentrations of PM and trace elements in PM.

\begin{tabular}{ccccccccc}
\hline & $\mathrm{PM}$ & $\mathrm{Fe}$ & $\mathrm{Mn}$ & $\mathrm{Ti}$ & $\mathrm{Pb}$ & $\mathrm{Cr}$ & $\mathrm{Cu}$ & $\mathrm{Ni}$ \\
\hline$R^{2}$ & 0.46 & 0.74 & 0.94 & 0.65 & 0.83 & 0.50 & 0.99 & 0.00
\end{tabular}

Title Page

Abstract

Introduction

Conclusions

References

Tables

Figures

14

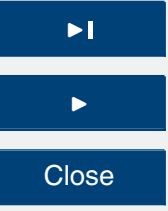

Back

Full Screen / Esc

Printer-friendly Version

Interactive Discussion 
Table 2. All combinationas of elements for solutions obtained by calculation by Unmix.

\begin{tabular}{|c|c|c|c|c|}
\hline Combination of species & $\begin{array}{l}\text { Number } \\
\text { of sources }\end{array}$ & $\operatorname{Min} R^{2}$ & $\operatorname{Min} S / N$ & Significant/strong species in sources ( $\sigma$-based) \\
\hline $\mathrm{Mn}-\mathrm{Ti}-\mathrm{Pb}-\mathrm{Cr}-\mathrm{Cu}$ & $\begin{array}{l}3 \\
4 \\
5\end{array}$ & $\begin{array}{l}0.84 \\
0.89 \\
0.90\end{array}$ & $\begin{array}{l}2.49 \\
1.94 \\
1.59\end{array}$ & $\begin{array}{l}\text { Source 1: } \text { Strong }^{*}-\mathrm{Pb} \text {; } \\
\text { Source 2: Strong } \\
\text { Source 3: Strong } \\
\text { S }-\mathrm{Cr} \text {, Cu, Significant }{ }^{* *}-\mathrm{Ti} \text { Significant }{ }^{* *}-\text { None }\end{array}$ \\
\hline $\mathrm{Cr}-\mathrm{Cu}-\mathrm{Pb}-\mathrm{Ti}-\mathrm{Mn}-\mathrm{Se}-\mathrm{Cd}-\mathrm{Co}-\mathrm{Fe}$ & $\begin{array}{l}3 \\
4\end{array}$ & $\begin{array}{l}0.68 \\
0.76\end{array}$ & $\begin{array}{l}2.41 \\
2.13\end{array}$ & \\
\hline $\mathrm{Cu}-\mathrm{Ti}-\mathrm{Fe}-\mathrm{Mn}-\mathrm{Pb}-\mathrm{Cr}-\mathrm{Hg}-\mathrm{Se}$ & 2 & 0.56 & 2.29 & \\
\hline Fe-Mn-Ti-Pb & 3 & 0.90 & 2.85 & $\begin{array}{l}\text { Source 1: } \text { Strong }^{*}-\text { None, Significant } \\
\text { Source 2: } \text { Strong }^{*}-\mathrm{PM}, \mathrm{Pb}, \mathrm{Fe} \\
\text { Sone Significant } \\
\text { Source 3: } \text { Strong }^{*}-\mathrm{Pb}, \mathrm{Pn}, \mathrm{Fe}, \mathrm{Mn} \text {, Significant }\end{array}$ \\
\hline Fe-Mn-Ti-Pb-Cr-Cu-Ni & $\begin{array}{l}3 \\
4 \\
5\end{array}$ & $\begin{array}{l}0.76 \\
\mathbf{0 . 8 3} \\
0.89\end{array}$ & $\begin{array}{l}2.20 \\
2.18 \\
1.67\end{array}$ & $\begin{array}{l}\text { Source 1: Strong }{ }^{*}-\mathrm{Cr}, \mathrm{Ni} \text {, Significant }{ }^{* *}-\mathrm{None} \\
\text { Source 2: Strong }{ }^{*} \text { - None, Significant }{ }^{* *}-\mathrm{Cu} \text {; } \\
\text { Source 3: Strong }{ }^{*}-\mathrm{Pb} \text {, Significant }{ }^{* *}-\mathrm{PM}, \mathrm{Cr}, \mathrm{Cu}, \mathrm{Ti}, \mathrm{Fe}, \mathrm{Mn} \text {; } \\
\text { Source 4: Strong }{ }^{*}-\mathrm{Ti} \text {, Significant }{ }^{* *}-\mathrm{PM}, \mathrm{Cr}, \mathrm{Pb}, \mathrm{Fe}\end{array}$ \\
\hline Fe-Mn-Ti-Pb-Cr-Cu & $\begin{array}{l}3 \\
4 \\
5\end{array}$ & $\begin{array}{l}\mathbf{0 . 8 3} \\
0.88 \\
0.90\end{array}$ & $\begin{array}{l}2.57 \\
1.97 \\
1.62\end{array}$ & $\begin{array}{l}\text { Source 1: } \text { Strong }^{*}-\mathrm{Pb}, \text { Significant } \\
\text { So }-\mathrm{Cu} \\
\text { Source 2: Strong } \\
\text { Source 3: Strong } \\
\text { Sone, Significant }\end{array}$ \\
\hline
\end{tabular}

${ }^{*}$ Source composition $\geq 1 \sigma ;{ }^{* *}$ source composition $\geq 2 \sigma$. The satisfactory solutions are in bold.

\section{Applying receptor models Unmix and PMF on real data set of elements in PM \\ D. Đorđević et al.}

\section{Title Page}

Abstract

Introduction

Conclusions

References

Tables

Figures

14

$>1$

4

Back

Close

Printer-friendly Version

Interactive Discussion 
Table 3. $R^{2}$ values obtained by PMF of measured and the predicted concentrations.

\begin{tabular}{llccc}
\hline Species & Category & \multicolumn{3}{c}{$R^{2}$} \\
\cline { 3 - 5 } & & 3 sources & 4 sources & 5 sources \\
\hline $\mathrm{Cr}$ & Strong & 0.617 & 0.980 & 0.998 \\
$\mathrm{Ti}$ & Strong & 0.381 & 0.962 & 0.959 \\
$\mathrm{Fe}$ & Strong & 0.401 & 0.472 & 0.942 \\
$\mathrm{~Pb}$ & Strong & 0.695 & 0.701 & 0.905 \\
$\mathrm{Mn}$ & Weak & 0.394 & 0.340 & 0.528 \\
$\mathrm{Cu}$ & Strong & 0.345 & 0.337 & 0.473 \\
$\mathrm{Ni}$ & Weak & 0.027 & 0.031 & 0.025 \\
$\mathrm{Co}$ & Weak & 0.006 & 0.013 & 0.018 \\
$\mathrm{Hg}$ & Weak & 0.002 & 0.005 & 0.003 \\
\hline
\end{tabular}

Applying receptor models Unmix and PMF on real data set of elements in PM

D. Đorđević et al.

\section{Title Page}

Abstract

Introduction

Conclusions

References

Tables

Figures

14

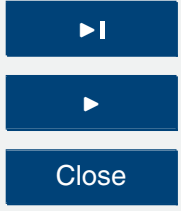

Back

Full Screen / Esc

Printer-friendly Version

Interactive Discussion 

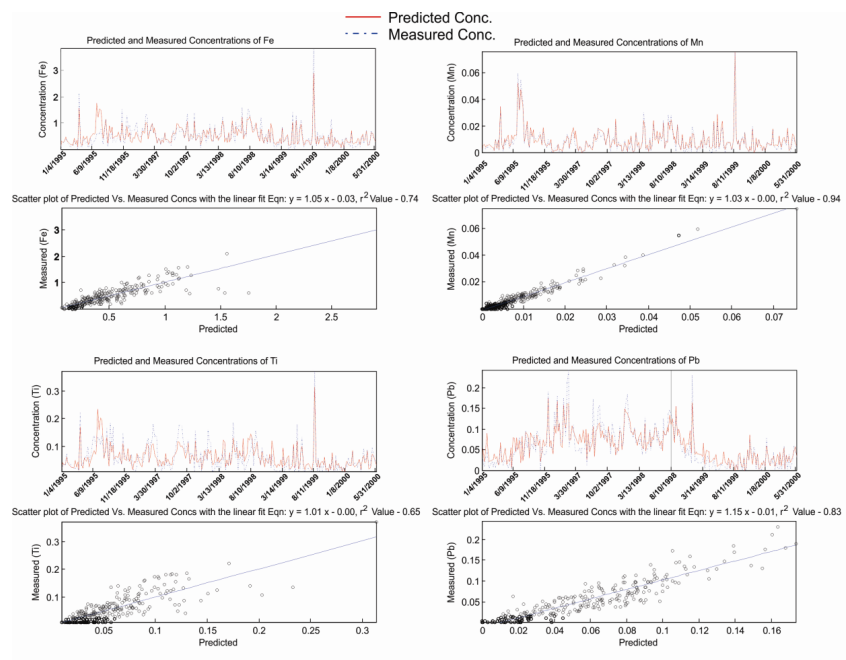

\section{AMTD}

6, 4941-4969, 2013

\section{Applying receptor models Unmix and PMF on real data set of elements in PM}

D. Đorđević et al.
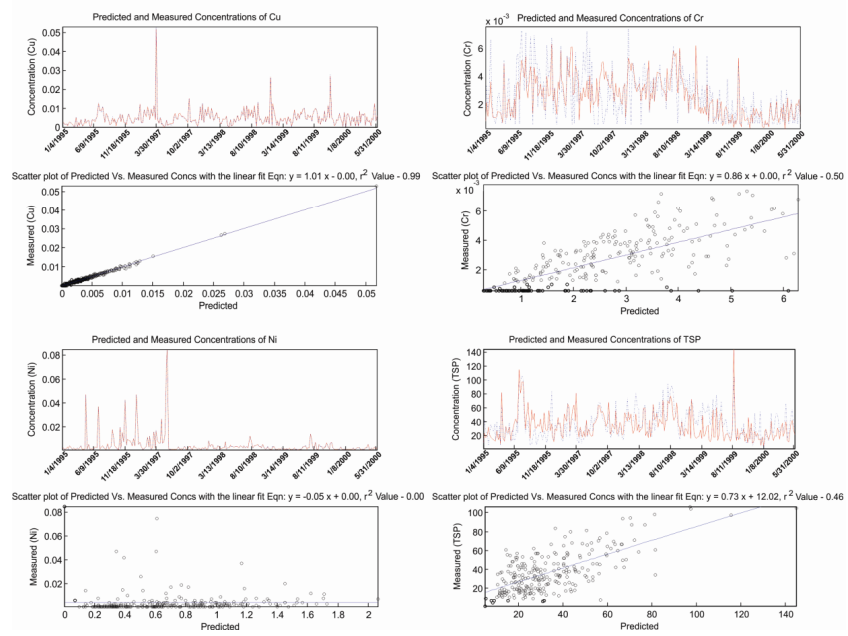

Title Page

Abstract

Introduction

Conclusions

References

Tables

Figures

14

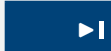

4

Back

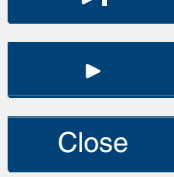

Full Screen / Esc

Printer-friendly Version

Interactive Discussion

Fig. 1. Predicted and measured concentrations. 

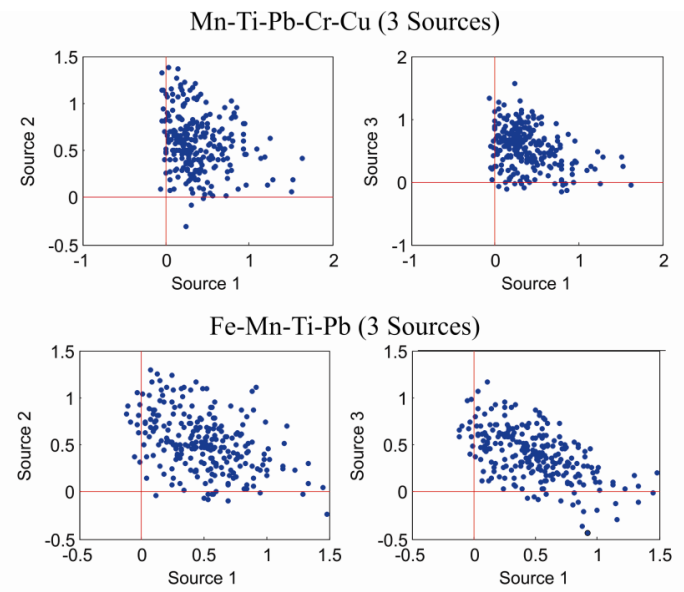

$\mathrm{Fe}-\mathrm{Mn}-\mathrm{Ti}-\mathrm{Pb}-\mathrm{Cr}-\mathrm{Cu}-\mathrm{Ni}$ (3 Sources)
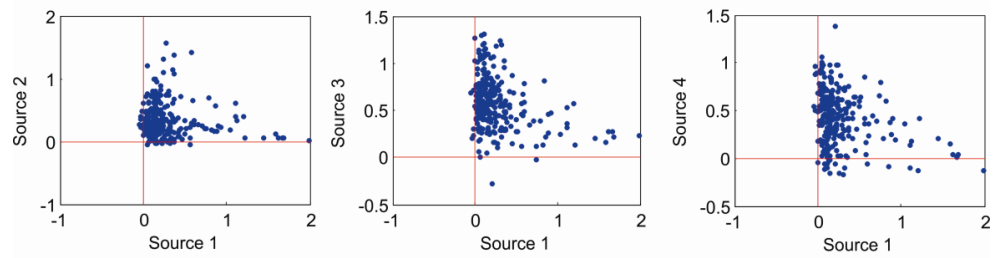

$\mathrm{Fe}-\mathrm{Mn}-\mathrm{Ti}-\mathrm{Pb}-\mathrm{Cr}-\mathrm{Cu}$ (3 Sources)
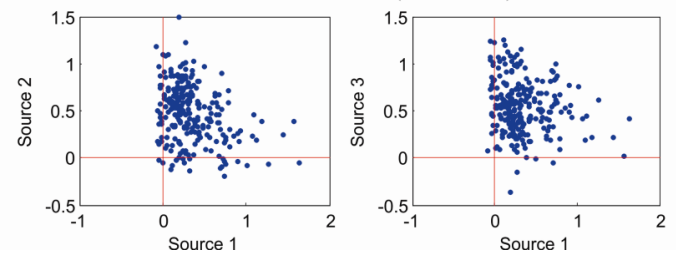

Fig. 2. Edge plots for chosen solutions that satisfy the conditions of Min $S / N$ and Min $R^{2}$.

AMTD

6, 4941-4969, 2013

\section{Applying receptor} models Unmix and PMF on real data set of elements in PM

D. Đorđević et al.

Title Page

Abstract

Introduction

Conclusions

References

Tables

Figures

14

4

Back

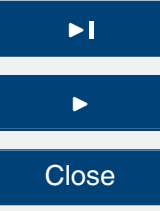

Full Screen / Esc

Printer-friendly Version

Interactive Discussion 

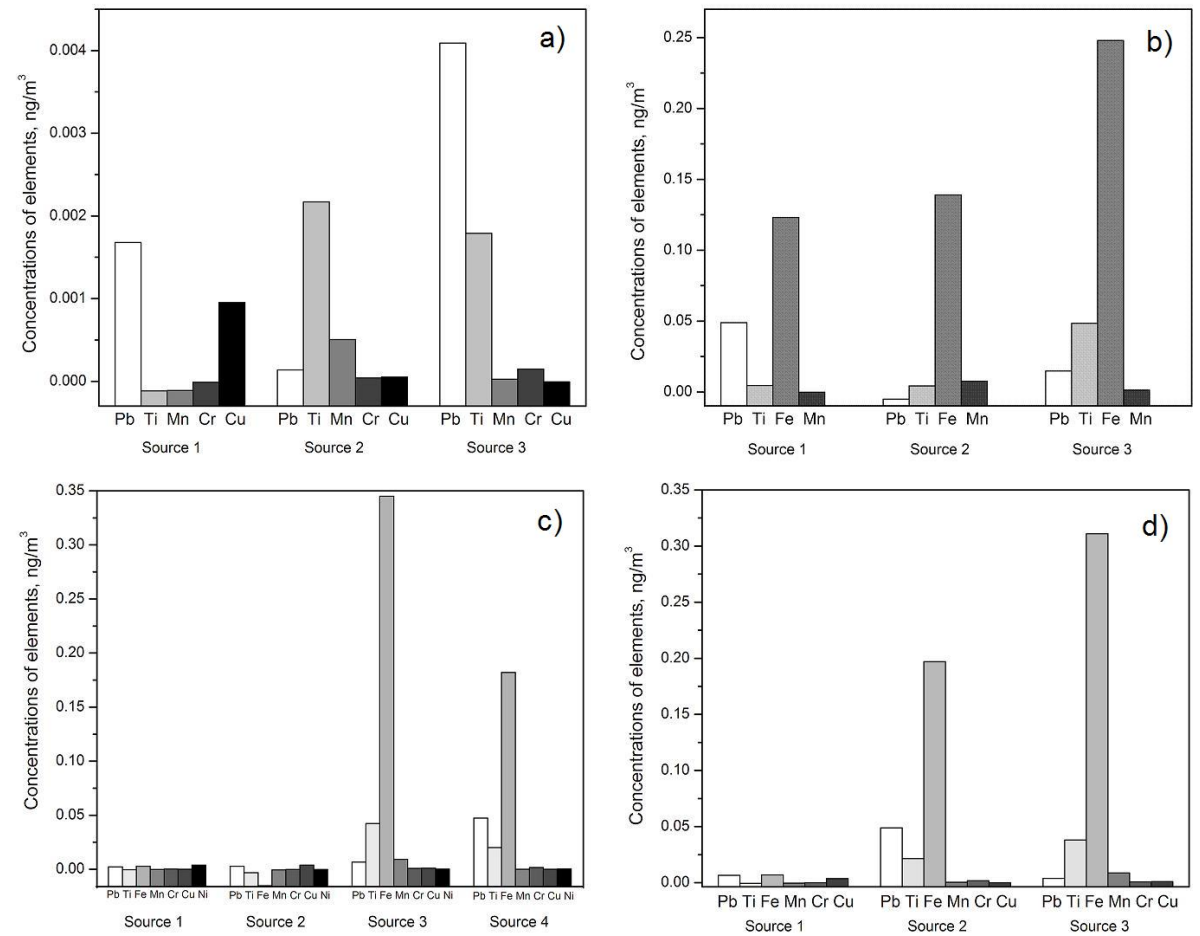

AMTD

6, 4941-4969, 2013

\section{Applying receptor models Unmix and PMF on real data set of elements in PM \\ D. Đorđević et al.}

Title Page

Abstract

Introduction

Conclusions

References

Tables

Figures

14

DI

4

Back

lose

Full Screen / Esc

Fig. 3. Source profiles for selected solutions that are in accordance with the Unmix criteria.

Printer-friendly Version

Interactive Discussion

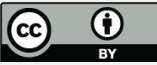



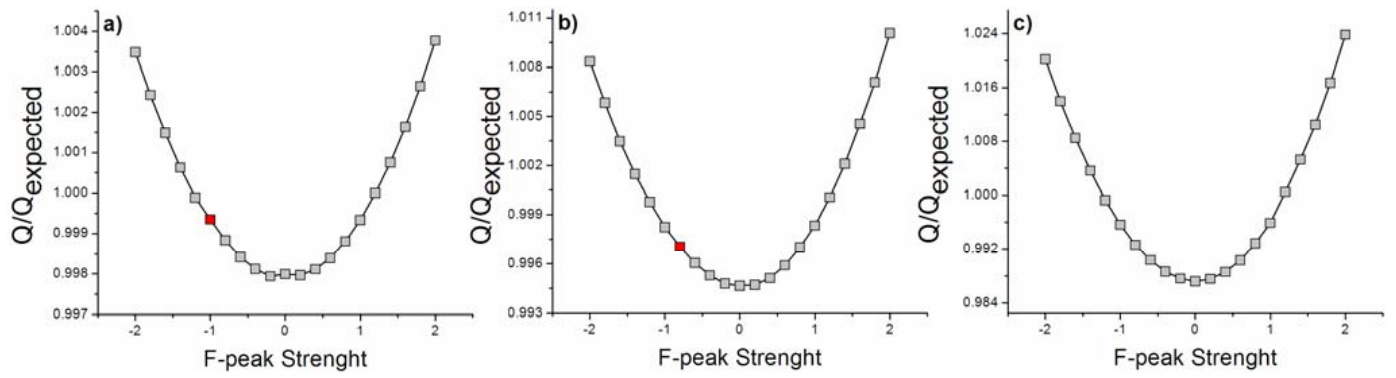

Fig. 4. $F$ peak analysis for three (a), four (b) and five (c) source solutions. The red mark represents the value of $F$ peak Strength, at which the rotational ambiguity disappears.

\section{AMTD}

$6,4941-4969,2013$

\section{Applying receptor models Unmix and PMF on real data set of elements in PM}

D. Đorđević et al.

\section{Title Page}

Abstract

Introduction

Conclusions

References

Tables

Figures

14

Back

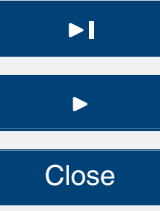

Full Screen / Esc

Printer-friendly Version

Interactive Discussion 


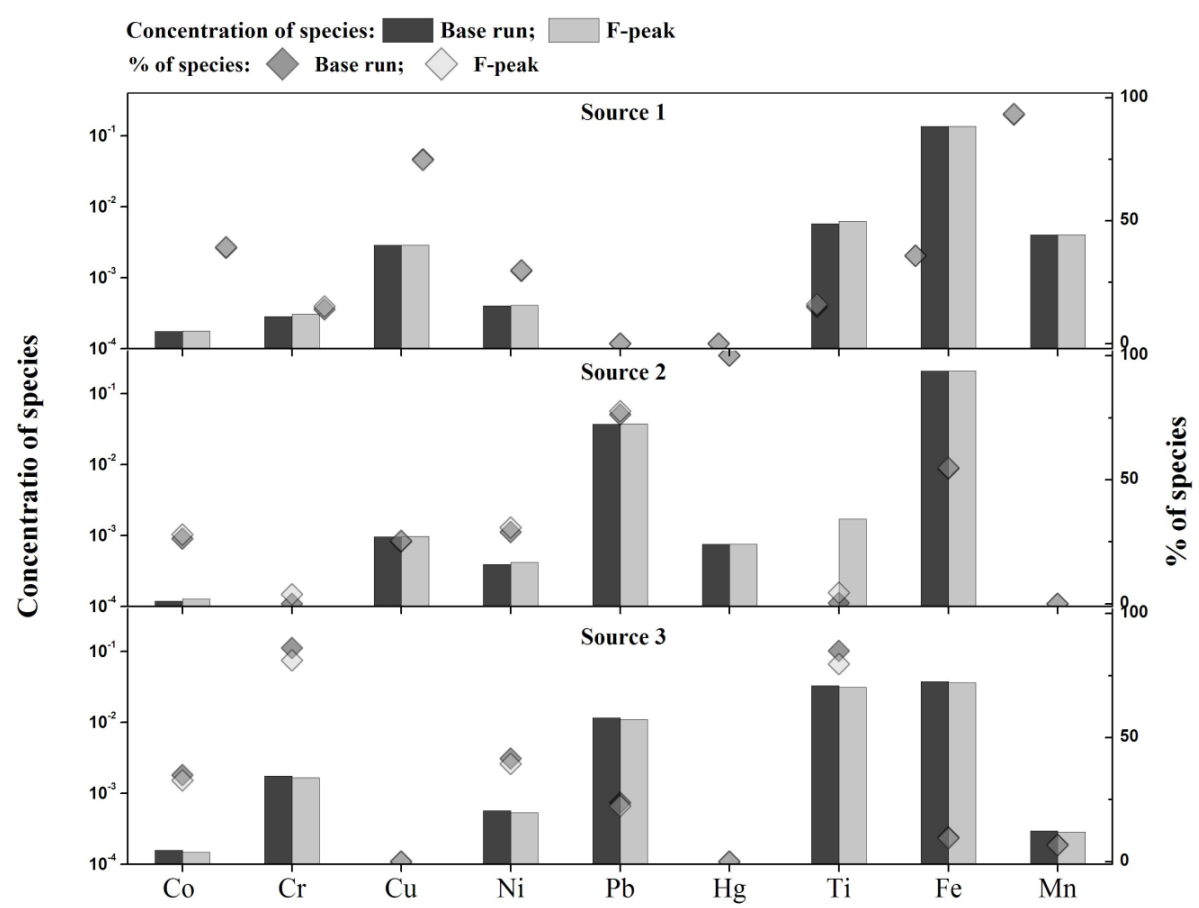

Fig. 5. Profiles in the case of three sources solutions. Comparison of base run profile and $F$ peak run profile with the strength of -1.2 (disappearance of rotational ambiguity).
AMTD

$6,4941-4969,2013$

Applying receptor models Unmix and PMF on real data set of elements in PM

D. Đorđević et al.

\section{Title Page}

Abstract

Introduction

Conclusions

References

Tables

Figures

14

4

Back

Close

Full Screen / Esc

Printer-friendly Version

Interactive Discussion 


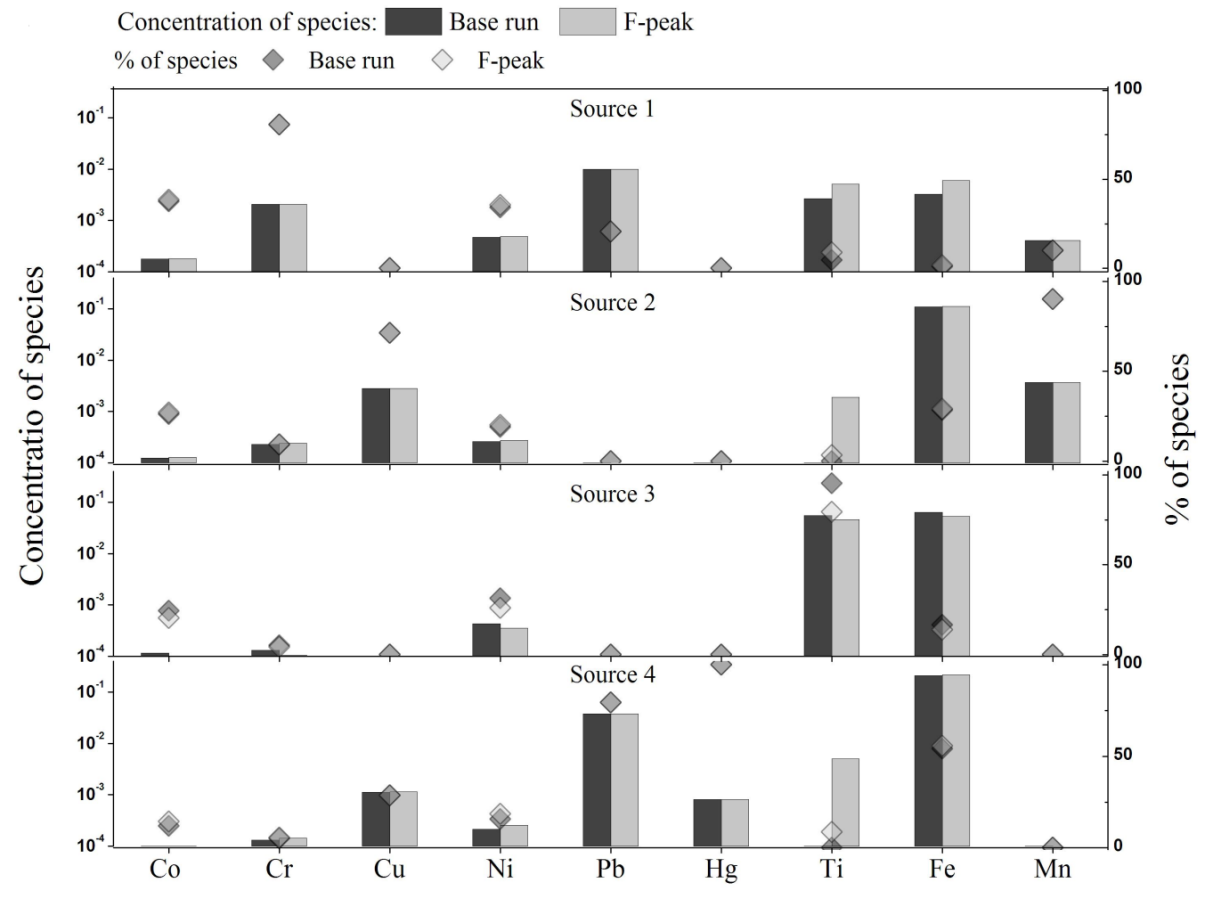

Fig. 6. Profiles in the case of four sources solutions. Comparison of base run profile and $F$ peak run profile with the strength of -0.8 (disappearance of rotational ambiguity).

\section{AMTD}

6, 4941-4969, 2013

\section{Applying receptor models Unmix and PMF on real data set of elements in PM \\ D. Đorđević et al.}

Title Page

Abstract

Introduction

Conclusions

References

Tables

Figures

14

4

Back

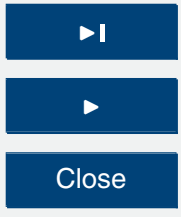

Full Screen / Esc

Printer-friendly Version

Interactive Discussion 


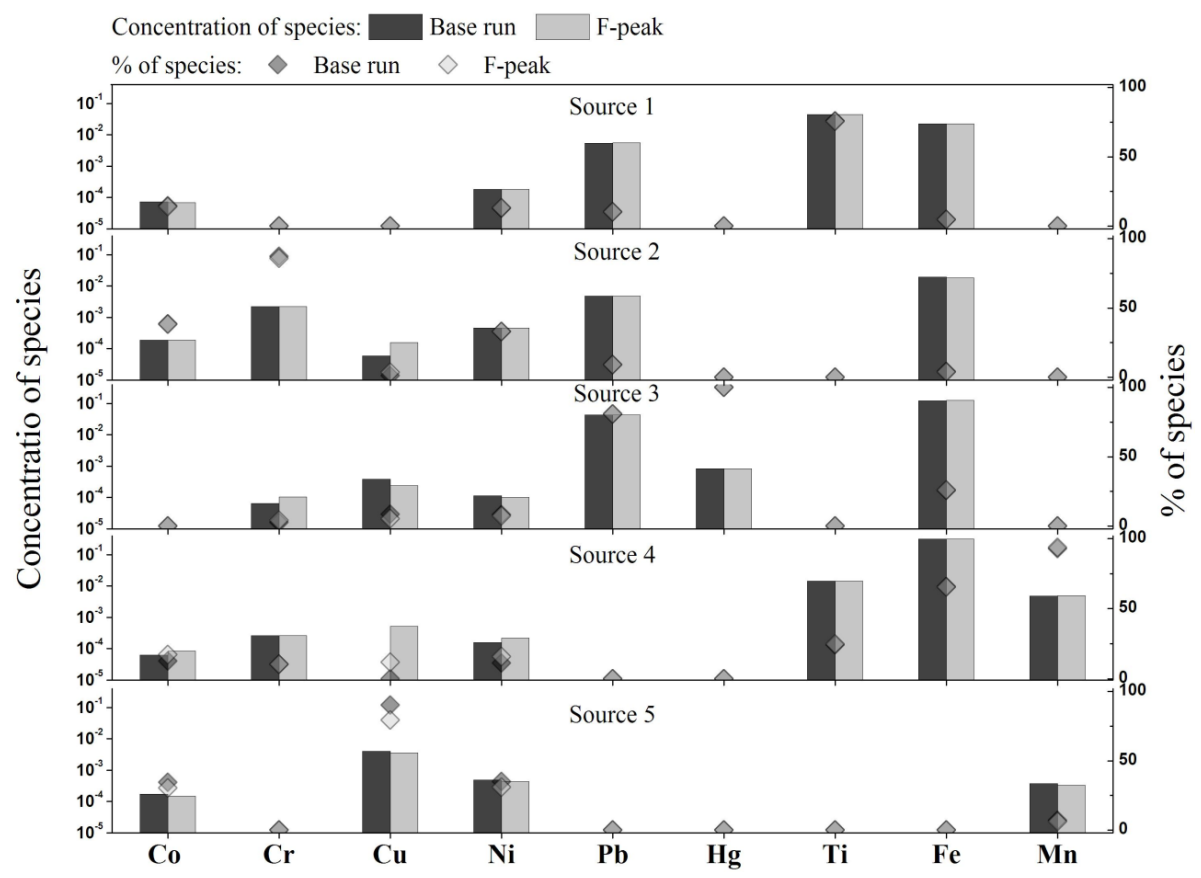

AMTD

6, 4941-4969, 2013

Applying receptor models Unmix and PMF on real data set of elements in PM

D. Đorđević et al.

Title Page

Abstract

Introduction

Conclusions

References

Tables

Figures

14

4

Back

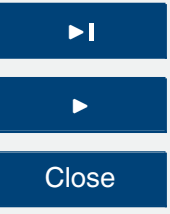

Full Screen / Esc run profile with the strength of -2.0 where it can be seen that $F$ peak Strength does not affect the existing rotational ambiguity.

Printer-friendly Version

Interactive Discussion 


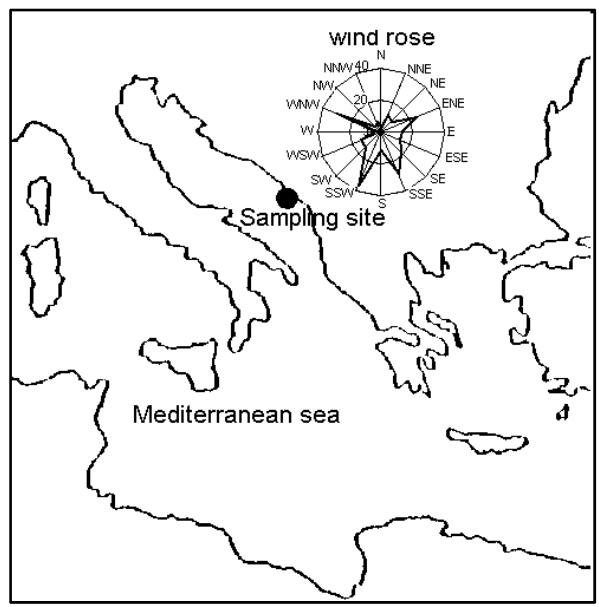

AMTD

$6,4941-4969,2013$

\section{Applying receptor models Unmix and PMF on real data set of elements in PM \\ D. Đorđević et al.}

Title Page

Abstract

Introduction

Conclusions

References

Tables

Figures

14

DI

Fig. 8. Sampling site and prevailing wind directions.

Full Screen / Esc

Printer-friendly Version

Interactive Discussion 